\title{
2008s-07 \\ Institutions and Multinational Ownership Strategy
}

\author{
Ari Van Assche, Galina A. Schwartz
}

\begin{tabular}{c}
\hline Série Scientifique \\
Scientific Series
\end{tabular}

\author{
Montréal \\ Mars 2008
}

(C) 2008 Ari Van Assche, Galina A. Schwartz. Tous droits réservés. All rights reserved. Reproduction partielle permise avec citation du document source, incluant la notice (C).

Short sections may be quoted without explicit permission, if full credit, including (C) notice, is given to the source.

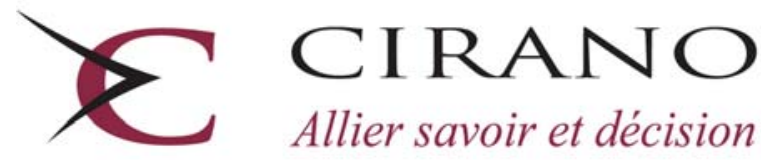

Centre interuniversitaire de recherche en analyse des organisations 


\section{CIRANO}

Le CIRANO est un organisme sans but lucratif constitué en vertu de la Loi des compagnies du Québec. Le financement de son infrastructure et de ses activités de recherche provient des cotisations de ses organisations-membres, d'une subvention d’infrastructure du Ministère du Développement économique et régional et de la Recherche, de même que des subventions et mandats obtenus par ses équipes de recherche.

CIRANO is a private non-profit organization incorporated under the Québec Companies Act. Its infrastructure and research activities are funded through fees paid by member organizations, an infrastructure grant from the Ministère du Développement économique et régional et de la Recherche, and grants and research mandates obtained by its research teams.

\section{Les partenaires du CIRANO}

\section{Partenaire majeur}

Ministère du Développement économique, de l’Innovation et de l’Exportation

\section{Partenaires corporatifs}

Alcan inc.

Banque de développement du Canada

Banque du Canada

Banque Laurentienne du Canada

Banque Nationale du Canada

Banque Royale du Canada

Banque Scotia

Bell Canada

BMO Groupe financier

Bourse de Montréal

Caisse de dépôt et placement du Québec

DMR Conseil

Fédération des caisses Desjardins du Québec

Gaz de France

Gaz Métro

Hydro-Québec

Industrie Canada

Investissements PSP

Ministère des Finances du Québec

Raymond Chabot Grant Thornton

State Street Global Advisors

Transat A.T.

Ville de Montréal

\section{Partenaires universitaires}

École Polytechnique de Montréal

HEC Montréal

McGill University

Université Concordia

Université de Montréal

Université de Sherbrooke

Université du Québec

Université du Québec à Montréal

Université Laval

Le CIRANO collabore avec de nombreux centres et chaires de recherche universitaires dont on peut consulter la liste sur son site web.

Les cahiers de la série scientifique (CS) visent à rendre accessibles des résultats de recherche effectuée au CIRANO afin de susciter échanges et commentaires. Ces cahiers sont écrits dans le style des publications scientifiques. Les idées et les opinions émises sont sous l'unique responsabilité des auteurs et ne représentent pas nécessairement les positions du CIRANO ou de ses partenaires.

This paper presents research carried out at CIRANO and aims at encouraging discussion and comment. The observations and viewpoints expressed are the sole responsibility of the authors. They do not necessarily represent positions of CIRANO or its partners. 


\title{
Institutions and Multinational Ownership Strategy ${ }^{*}$
}

\author{
Ari Van Assche ${ }^{\dagger}$, Galina A. Schwartz ${ }^{\ddagger}$
}

\begin{abstract}
Résumé / Abstract
Ce papier examine l'impact des institutions sur la stratégie de propriété d'une entreprise multinationale. Nous développons un modèle de coentreprise internationale dans lequel une entreprise étrangère et son partenaire local peuvent ex post entreprendre des actions coûteuses pour augmenter leur part de revenus indiquée dans le contrat de coentreprise. Le modèle analyse les impacts de deux caractéristiques institutionnelles sur la structure de propriété optimale : le renforcement du contrat et le copinage. Nous introduisons le modèle de coentreprise dans un modèle d'équilibre général pour analyser l'impact des institutions sur le mode d'entrée des entreprises multinationales.
\end{abstract}

Mots clés : coentreprise internationale, renforcement du contrat, copinage.

This paper examines the impact of institutions on a multinational firm's ownership strategy. We develop an international joint venture (IJV) model in which a multinational firm and its local partner both can undertake costly ex post actions to increase their revenue share specified by the ex ante IJV contract. The model captures the effects of two institutional features on the optimal IJV ownership structure: contract enforceability and cronyism. We introduce the IJV model into an industry equilibrium framework to analyze the impact of institutions on a multinational firm's choice between forming an IJV or setting up a whollyowned subsidiary.

Keywords: liability of foreignness, international joint venture, contract enforceability, cronyism.

Codes JEL : F23, F12.

\footnotetext{
* We thank Phelim Boyle, Nathan Jensen, Justin Leroux, Suzanne Rivard, Nicolas Sahuguet and seminar participants at the Université de Québec à Montréal, Carleton University and the Katholieke Universiteit Leuven for helpful comments and suggestions. Ari Van Assche thanks the fonds québécois de la recherche sur la société et la culture (FQRSC) for financial support.

† HEC Montréal, Department of International Business, 3000, Chemin de la Côte-Sainte-Catherine, Montréal (Québec), Canada, H3T2A7. Phone: (514)340-6043. Fax: (514)340-6987. E-mail: ari.van-assche@hec.ca.

$\ddagger$ University of California, Berkeley.
} 


\section{Introduction}

A long-standing stylized fact in international economics is that firms face a liability of foreignness (LOF) when doing business abroad (Hymer, 1976). ${ }^{1}$ Foreign firms have less information about the host country than local firms. They may also receive inferior treatment from the host country government due to their relative lack of connections with local officials. LOF has become a key building block in theories of the multinational firm, which motivates the paradigm that multinational firms need firm-specific advantages to compete successfully against local firms (Buckley and Casson, 1976; Caves, 1982; Dunning, 1977; Hennart, 1982).

Despite the importance of LOF in theories of the multinational firm, formal studies of its effects on a multinational firm's entry strategy are scant. $^{2}$ The effects are not straightforward. Forming an international joint venture (IJV) with a local firm is generally considered to mitigate LOF by allowing a multinational firm to tap into its local partner's resources and connections (Hennart, 1988, 1991; Inkpen and Beamish, 1997; Luo, 2002). The multinational firm can for example use its local partner's relations with government officials to obtain the required business licenses to set up the IJV. Less considered, however, is the fact that once a multinational firm is locked into an IJV, its local partner's superior market knowledge and contacts remain. In weak institutional environments, a local partner then may have the possibility to use this ex post advantage to get extra private benefits from the IJV at the detriment of the multinational firm (Henisz, 2000; Perkins et al., 2007).

The following example by Desai and Moel (2008) demonstrates the effects of such an ex post LOF. In the early 1990s, the U.S.-invested enterprise CME formed an IJV with the Czech company CET-21 to enter the Czech media market. This joint venture was considered beneficial since it should reduce CME's ex ante LOF. Indeed, CME counted on the strong market knowledge of CET-21's owner Vladimir Zelezny to ensure locally appropriate television programming. ${ }^{3}$ Moreover, by forming an IJV, CME wanted to circumvent the political opposition against giving television licenses to foreign investors by assigning the ownership of the license to CET-21. The partners' IJV contract then specified that CME had exclusive user rights over the license.

\footnotetext{
${ }^{1}$ In recent work, however, Huang (2005) has found that foreign firms often enjoy regulatory advantages over weakly connected local firms.

${ }^{2}$ See Zaheer (1995, 2002) and Eden and Miller (2004) for recent surveys of the international business literature on this topic.

${ }^{3}$ An interesting anecdote: Zelezny means "man of iron" in Russian.
} 
The IJV's television station launch was highly successful. In its first year of operation, it gained a 70 percent share of the Czech television audience. In the second half of the 1990s, however, the partnership turned sour. At that time, Zelezny successfully used his government contacts to obtain a ruling that CME could no longer have exclusive use of the license. This decision allowed CET-21 to expropriate CME's rents from the joint venture.

The example demonstrates that well-connected local firms in weak institutional environments may have the ability to manipulate local officials to expropriate rents from their multinational partners (Desai and Moel, 2008). This ability affects a multinational firm's ownership strategy in two ways. First, it reduces the attractiveness of entering a foreign market through joint ventures with local firms. Second, it affects the ex post distribution of rents between IJV partners, thus distorting their incentives to contribute specific investments. Therefore, it also affects the optimal IJV ownership structure.

Local firms' ability to ex post expropriate rents depends on the host country's institutional environment. Specifically, two institutional features need to coexist. On one hand, cronyism needs to exist so that local officials give preference to well-connected local firms. On the other hand, IJV contracts need to be imperfectly enforceable so that the local firm can ex post take actions to take advantage of cronyism.

This paper examines the impact of these institutional features on a multinational firm's ownership strategy. In Section 2, we set up an IJV model in which a multinational firm first (ex ante) signs a revenue-sharing contract with a local firm. Then each party provides specialized inputs to the IJV to create joint revenue. Finally (ex post), parties can conduct costly actions to increase their revenue share. Such rent-seeking actions include government lobbying, gifts and bribes.

Our model captures the institutional features of contract enforceability and cronyism by modelling IJV partners' "bribing" environments. The stricter a country's legal system is in enforcing contracts, the lower the incentives for parties to violate the stipulations of the original contract. In our model, we thus represent contract enforceability with a parameter that corresponds to parties' costs of ex post taking rent-seeking actions. To model cronyism, we let the cost of these ex post actions be lower for local firms than for multinational firms. An increase in disparity between parties' costs of ex post actions then implies more pervasive cronyism.

The results of Section 2 are as follows. Both contract enforceability and cronyism affect a multinational firm's ownership strategy. A reduction in contract enforceability negatively affects IJV performance by (i) creating wasteful ex post expenses and (ii) distorting partners' investment incentives. 
In distorting incentives, it disproportionately weakens those of the minority partner (i.e., the partner with a smaller ownership share). We find that it is thus optimal to deal with lower contract enforceability by allocating a larger ownership share to the minority partner. Cronyism also distorts partners' investment incentives by strengthening those of the local firm while weakening those of the multinational firm. We find that it is therefore optimal to deal with cronyism by allocating a higher ownership share to the multinational firm. Interestingly, we find that cronyism does not necessarily reduce IJV performance. Rather, it lowers the feasibility of an IJV. In sum, IJV partners need to take into account both institutional features to determine their optimal IJV ownership structure.

In Section 3, we introduce our IJV model into an industry equilibrium framework to analyze the impact of the institutional features on a multinational firm's entry mode. In this framework, heterogeneous multinational firms choose from two modes: (i) they can form an IJV or (ii) they can set up a wholly-owned subsidiary. There is an intrinsic trade-off between these modes. If a multinational firm forms an IJV, it gains a lower fixed cost of entry since it can tap into the local partner's market-specific knowledge and contacts. But it faces higher transaction costs due to imperfect contract enforceability and cronyism. Inversely, setting up a subsidiary permits it to gain lower transaction costs at a higher fixed entry cost. We find that for more productive multinational firms, setting up a wholly-owned subsidiary is optimal, and forming the IJV is optimal for less productive firms.

Our paper is related to recent theoretical studies on the optimal revenuesharing contract in joint ventures. Bai et al. (2004) and Wang and Zhu (2005) set up joint venture models with incomplete contracting in which ownership and control are separately contractible. In these papers, ownership determines revenue-sharing, while control determines parties' ability to ex post take actions to acquire private benefits at a loss to the joint venture. Their setups allow them to simultaneously study the optimal structure of revenue sharing and control allocation in a joint venture. Our paper is similar to theirs in that we both study optimal revenue-sharing contracts in joint ventures. It differs, however, in that we do not model the allocation of control rights, but rather focus on the role of the institutional features on ex post actions. That is, ex post actions in our model are not driven by the allocation of control rights, but rather by the "bribing" environments in which IJV partners operates.

Our paper also builds onto the recent literature on contract enforcement 
and multinational firms' organizational decisions. ${ }^{4}$ This literature incorporates elements of incomplete contracts theory into general-equilibrium trade models to analyze the determinants of multinational firms' decisions to offshore and/or outsource their production activities. Our benchmark model closely resembles that of Antràs and Helpman (2004). By introducing costly ex post actions into it, we contribute to this literature new analytical underpinnings to study the impact of the institutional features of contract enforceability and cronyism on a multinational firm's organization. In this paper, we apply our setup to study the multinational firm's optimal ownership strategy in a foreign market.

The rest of the paper is organized as follows. Section 2 sets up the IJV model. Section 3 incorporates the IJV model into an industry-equilibrium framework. Section 4 concludes.

\section{IJV Model}

Consider a multinational firm $M$ that sets up an IJV with a local firm $D$. Let the IJV face an iso-elastic inverse demand function for its output $y$ :

$$
p=\lambda^{1-\alpha} y^{\alpha-1}
$$

where $p$ denotes price, the constant $\alpha \in[0,1 / 2]$ determines the elasticity of demand and the constant $\lambda>0$ reflects the level of demand. ${ }^{5}$

Production of final good $y$ requires two complementary inputs: foreign inputs $m$ produced by the multinational firm at unit cost $\rho$ and local inputs $d$ produced by the local firm at unit cost $\omega$. We assume that the inputs are relationship-specific, that is, they have zero outside value if the IJV relationship breaks down. The IJV produces final good $y$ from inputs $m$ and $d$ via a Cobb-Douglas production function: ${ }^{6}$

$$
y=\theta\left(\frac{m}{\eta}\right)^{\eta}\left(\frac{d}{1-\eta}\right)^{1-\eta},
$$

where the constant $\theta$ reflects the IJV's productivity and $\eta \in[0,1]$ is a parameter characterizing the intensity of foreign inputs in IJV production.

\footnotetext{
${ }^{4}$ This literature includes studies by Grossman and Helpman (2002, 2003, 2005); Antràs (2003, 2005) and Antràs and Helpman (2004, 2008). See Spencer (2005) and Helpman (2006) for recent surveys of this literature.

${ }^{5}$ We assume that $\alpha \in[0,1 / 2]$ to guarantee the uniqueness of an equilibrium in section 2.3. See Appendix for more details.

${ }^{6}$ We have purposefully adopted many of the functional forms and notation from Antràs and Helpman (2004) to ease comparison with the results of their paper.
} 
By combining (1) and (2), the IJV's revenue can be expressed as

$$
R(m, d)=\lambda^{1-\alpha} \theta^{\alpha}\left(\frac{m}{\eta}\right)^{\alpha \eta}\left(\frac{d}{1-\eta}\right)^{\alpha(1-\eta)} .
$$

We assume that revenue $R$ is verifiable by an outside party, but that the quality of inputs is unverifiable. To induce the parties to provide the required specific inputs, they can sign a linear revenue-sharing contract that links their incomes to the verifiable joint revenue. ${ }^{7}$ Specifically, the multinational firm can propose a take-it-or-leave-it IJV contract to a local firm that specifies (i) the multinational firm's ownership share $s \in[0,1]$ that gives it right to revenue share $s$ and (ii) a fixed lump-sum payment $t$ between the two parties that takes place ex ante, i.e. prior to the production of inputs.

The IJV operates in an institutional environment where parties can ex post take costly actions to adjust the ex ante determined allocation of revenue. After parties have produced their inputs and revenue is realized, each party $i \in\{M, D\}$ can spend private resources or "bribes" to increase its revenue share by $r_{i}{ }^{8}$ Let $v$ and $1-v$ denote the ex post revenue share for the multinational and local firm respectively. Parties ex post choose $r_{m}$ and $r_{d}$ so that the multinational firm's ex post revenue share

$$
v=s+r_{m}-r_{d}
$$

We assume that the ex post actions are costly. To improve its ex post revenue share with $r_{i}$, a party incurs the bribing expense $B\left(r_{i}\right)$, which is increasing and concave in adjustment $r_{i}$ :

$$
B\left(r_{i}\right)=\left\{\begin{array}{cl}
e^{\frac{r_{i}}{\gamma_{i}}} & \text { if } r_{i}>0 \\
0 & r_{i}=0
\end{array}\right.
$$

In the "bribe function" $B$, the parameter $\gamma_{i}$ reflects the bribing environment in which party $i$ operates. ${ }^{9}$ The higher $\gamma_{i}$, the lower the bribe $B$ that party $i$ pays to increase its revenue share by $r_{i}$. We infer from this that an increase

\footnotetext{
${ }^{7}$ Such linear contracts are widespread in business practices due to their their simplicity and transparency. They are also widely adopted by the literature on joint ventures, see Bai et al. (2004) and Wang and Zhu (2005).

${ }^{8}$ We for simplicity call these rent-seeking actions "bribes". More accurately, these actions encompass all legal and illegal ex post transactional activities including legal expenses, government lobbying and gifts.

${ }^{9}$ Our bribe function implies that a party has to pay a fixed cost of 1 to bribe. This assumption can easily be generalized to account for a fixed bribing cost of any size.
} 
in party $i$ 's bribing parameter $\gamma_{i}$ strengthens its incentives to undertake ex post actions.

The IJV parties' bribing parameters $\gamma_{i}$ capture two features of the host country's institutions: (i) contract enforceability and (ii) cronyism. First, we use the average of both parties' bribing parameters as a measure of contract enforceability. Let

$$
\gamma=\frac{\gamma_{m}+\gamma_{d}}{2}
$$

An increase in $\gamma$ then reflects lower contract enforceability. The intuition behind this is the following. If $\gamma$ is high (low), it is cheap (expensive) for a party to ex post violate the terms of the ex ante contract. As a result, parties have weak (strong) incentives to adhere to the ex ante contract. High (low) $\gamma$ thus corresponds to low (high) contract enforceability.

Second, we can use the difference between parties' bribing parameters $\gamma_{i}$ to characterize cronyism. Let

$$
\delta=\frac{\gamma_{d}-\gamma_{m}}{2}
$$

If $\delta>0$, the cost of ex post actions is lower for a local firm than for a multinational firm $\left(\gamma_{d}>\gamma_{m}\right)$. This corresponds to an environment in which officials give special treatment to well-connected local firms. We use $\delta$ to measure cronyism, with a higher $\delta$ reflecting more pervasive cronyism.

Note that combining (6) and (7) yields

$$
\gamma_{d}=\gamma+\delta \text { and } \gamma_{m}=\gamma-\delta
$$

where $\gamma \geq \delta \geq 0$. We infer from the latter condition that cronyism is dependent on contract enforceability. Specifically, cronyism $(\delta>0)$ can only be present if contracts are imperfectly enforceable $(\gamma>0)$. Below, we use (8) to insert the institutional parameters $\gamma$ and $\delta$ into the model.

The IJV model can be summarized by the following sequence of events. In period 1, the multinational firm offers a take-it-or-leave-it IJV contract $(s, t)$ to a local firm that specifies the multinational firm's ownership share $s$ and a lump-sum transfer $t$. In period 2, both parties produce their inputs $m$ and $d$. In period 3 , both parties can adjust the ex ante contract through costly actions $r_{m}$ and $r_{d}$. Below, we solve for the optimal IJV contract through backward induction.

The remainder of this section is divided into three parts. In subsection 2.1, we analyze the benchmark case of perfect contract enforcement where it is too costly for parties to conduct ex post actions. In subsection 2.2, we 
study the case of imperfect contract enforcement without cronyism to analyze the impact of contract enforceability on the optimal IJV contract and performance. In subsection 2.3 , we analyze the case of imperfect contract enforcement with cronyism to assess the impact of cronyism on the optimal IJV contract and performance.

\subsection{Perfect Contract Enforcement}

Consider the benchmark case of perfect contract enforcement where $\gamma_{i}=0$. For both parties, it is then infinitely costly to ex post conduct rent-seeking actions. As a result, it is optimal for each party $i$ in period 3 to choose

$$
\hat{r}_{i}=0,
$$

where the superscript ^denotes optimum under perfect contract enforcement. Both parties' ex post revenue shares then coincide with their ownership share:

$$
\hat{v}=s .
$$

Next, consider the parties' choices in period 2. Here they choose profitmaximizing inputs $m$ and $d$ for a given contract $(s, t)$ :

$$
\begin{gathered}
\max _{m} \pi_{m}=s R(m, d)-\rho m+t, \\
\max _{d} \pi_{d}=(1-s) R(m, d)-\omega d-t,
\end{gathered}
$$

where $\pi_{i}$ denotes party $i$ 's profits. By solving these problems and inserting them into (3), we can express revenue $R$ as a function of the multinational firm's ownership share $s$ :

$$
R(s)=\lambda\left[\alpha \theta\left(\frac{s}{\rho}\right)^{\eta}\left(\frac{1-s}{\omega}\right)^{1-\eta}\right]^{\frac{\alpha}{1-\alpha}} .
$$

In period 1 , the multinational firm offers a take-it-or-leave-it contract $(s, t)$ to its local partner that guarantees the local partner's participation in the IJV. It thus solves

$$
\max _{s, t} \pi_{m}=s R(s)-\rho m(s)+t
$$

subject to

$$
\pi_{d}=(1-s) R(s)-\omega d(s)-t \geq 0 .
$$


By solving for the optimal contract $(s, t)$, we derive an expression for a multinational firm's optimal ownership share:

$$
\hat{s}=\left\{\begin{array}{cc}
1 / 2 & \text { if } \eta=1 / 2 \\
\frac{\eta-\Psi}{2 \eta-1} & \text { if } \eta \neq 1 / 2
\end{array}\right.
$$

where

$$
\Psi=\alpha \eta(1-\eta)+\sqrt{\eta(1-\eta)(1-\alpha \eta)(1-\alpha+\alpha \eta)} .
$$

It is straightforward to show that $\Psi \in[0,1 / 2]$ and that $\Psi<\eta$ if $\eta<1 / 2$, while $\Psi>\eta$ if $\eta>1 / 2$. As a result, $\hat{s} \in[0,1]$.

[Figure 1 about here]

In Figure 1, we use (10) and (11) to plot as a solid curve the relation between ownership share $\hat{s}$ and the intensity of foreign inputs $\eta$. Ownership share $\hat{s}$ approaches zero when $\eta$ approaches 0 , it approaches 1 when $\eta$ approaches 1 , and it rises in between. Moreover, $\hat{s}$ is concave for $\eta<1 / 2$ and convex for $\eta>1 / 2$. These properties reflect that parties cannot contract upon the purchase of specialized inputs for a certain price. As a result, neither party appropriates the full marginal return to its investments in the supply of inputs, thus leading to underinvestment. Each party's incentives are then determined by its ownership share $s$. Ex ante efficiency thus requires giving a larger ownership share to the party undertaking the relatively more important investment into the IJV. As a result, the higher the intensity of foreign inputs (the larger $\eta$ is), the higher the multinational firm's ownership share $\hat{s}$ is. This leads to Proposition 1:

Proposition 1 Ceteris paribus, under perfect contract enforcement, the multinational firm's ownership share in an IJV rises with foreign input intensity.

Next, we can derive $\hat{\pi}_{m}$ by inserting the optimal contract $(\hat{s}, \hat{t})$ into $(9)$. This gives us

$$
\hat{\pi}_{m}=\lambda \Omega,
$$

where

$$
\Omega=\frac{(1-\alpha(1-\Psi))}{\left(\frac{2 \eta-1}{\alpha \theta}\left(\frac{\rho}{\eta-\Psi}\right)^{\eta}\left(\frac{\omega}{\eta+\Psi-1}\right)^{1-\eta}\right)^{\frac{\alpha}{1-\alpha}}} .
$$


Our benchmark model with perfectly enforceable contracts replicates a key result of Antràs and Helpman (2004). ${ }^{10}$ Next, we will use this benchmark to analyze the impact of the institutional features contract enforceability and cronyism on a multinational firm's ownership strategy.

\subsection{Contract Enforceability}

Consider the case of imperfect contract enforcement $(\gamma>0)$ without cronyism $(\delta=0)$. In this case, it is optimal for both parties to ex post engage in rent-seeking actions.

First, we derive parties' optimal ex post actions for a given $(s, t, m, d)$. Each party chooses the optimal amount $r_{i}$ that solves:

$$
\begin{gathered}
\max _{r_{m}} \pi_{m}=\left(s-r_{d}+r_{m}\right) R-B\left(r_{m}\right)-\rho m+t \\
\max _{r_{d}} \pi_{d}=\left(1-s+r_{d}-r_{m}\right) R-B\left(r_{d}\right)-\omega d-t,
\end{gathered}
$$

where the bribe function $B\left(r_{i}\right)$ is given by (5) and $R$ is short for $R=$ $R(s, t, m, d)$. The solutions of these problems yield

$$
r_{i}^{*}=\gamma \ln (\gamma R)
$$

where superscript * reflects optimum under imperfect contract enforcement. Inserting (16) into (5) then determines parties' bribes

$$
B\left(r_{i}^{*}\right)=\gamma R
$$

This suggests that both parties spend fraction $\gamma$ of revenue $R$ on bribes to increase their revenue share by $r_{i}^{*}{ }^{11}$ Since $r_{i}^{*}$ is identical for both parties, their effects on $v$ cancel each other out. Thus, each party's ex post revenue share is identical to its ownership share:

$$
v^{*}=s .
$$

In period 2, parties choose inputs $m$ and $d$ for a given $(s, t)$ :

$$
\max _{m} \pi_{m}=(s-\gamma) R(m, d)-\rho m+t
$$

\footnotetext{
${ }^{10}$ Our equations (10) (11), (12) and (13) are identical to Antràs and Helpman's (2004) equations (6), (7) and (10).

${ }^{11}$ Note that the IJV becomes unfeasible if $\gamma \geq \frac{1}{2}$. In that case, for at least one of both parties, the share of revenue that it needs to pay as a bribe $\gamma$ exceeds its ownership share. In our discussion below, we assume that $\gamma \leq \frac{1}{2}$.
} 


$$
\max _{d} \pi_{d}=(1-s-\gamma) R(m, d)-\omega d-t .
$$

By solving these problems and inserting them into (3), we can derive revenue as a function of $s$ :

$$
R^{*}(s)=\lambda\left[\alpha \theta\left(\frac{s-\gamma}{\rho}\right)^{\eta}\left(\frac{1-s-\gamma}{\omega}\right)^{1-\eta}\right]^{\frac{\alpha}{1-\alpha}} .
$$

It is straightforward to show from (17) that $R^{*}$ decreases with $\gamma$. The reason is that imperfect contract enforceability negatively affects both parties' incentives to produce inputs. When choosing their optimal amount of inputs, each party takes into account that, ceteris paribus, producing more inputs increases revenue and thus raises bribe $\gamma R$. This acts as a disincentive for parties to produce inputs.

The effect of imperfect contract enforceability on parties' incentives is not identical. While an increase in revenue induces both parties to increase their bribes equally, the ex post distribution of the extra revenue is not necessarily even. Specifically, the multinational firm ex post receives share $s$ of the extra revenue, while the local firm receives share $1-s$. We infer from this that the incentives of the minority partner in an IJV (i.e., the partner with a smaller ownership share) are affected more negatively by imperfect contract enforceability than those of the majority partner. Below, we show that this distortion of incentives affects the optimal ownership structure.

In period 1, the multinational firm offers a take-it-or-leave-it contract $(s, t)$ to the local firm that solves the problem

$$
\max _{s, t} \pi_{m}=(s-\gamma) R(s)-\rho m(s)+t
$$

subject to

$$
\pi_{d}=(1-s-\gamma) R(s)-\omega d(s)-t \geq 0 .
$$

By combining the solution of this problem with (10) and (11), we can relate the multinational firm's ownership share $s^{*}$ with its ownership share under perfect contract enforcement $\hat{s}$ :

$$
s^{*}=\hat{s}-\gamma \frac{1-2 \Psi}{2 \eta-1} .
$$

In Figure 1, we use (19) to plot the relation between ownership share $s^{*}$ and the intensity of foreign inputs $\eta$ as a dashed line. Similar to the benchmark 
case, $s^{*}$ increases with $\eta .{ }^{12}$ Contract enforceability affects the intersect and slope of the curve however. First, to ensure that both parties receive a sufficiently large share of revenue to pay the bribe $\gamma R, s^{*}$ approaches $\gamma$ when $\eta$ approaches 0 and $s^{*}$ approaches $1-\gamma$ when $\eta$ approaches 1 . Second, a comparison of (10) with (19) shows that the slope of $s^{*}$ is less steep than the slope of $\hat{s}$ and that the steepness of $s^{*}$ is positively related to contract enforceability $1 / \gamma$. This allows us to infer the following Proposition:

Proposition 2 When the multinational firm contributes relatively more to the IJV $(\eta>1 / 2)$, its ownership share decreases with $\gamma$. Otherwise $(\eta<$ $1 / 2)$, its ownership share increases with $\gamma$.

The intuition behind Proposition 2 is the following. Lower contract enforceability disproportionately reduces the incentives of the minority partner in the IJV. Since the multinational firm is the minority partner in a local-input intensive IJV $(\eta<1 / 2)$, it is optimal to allocate a larger ownership share to the multinational firm to improve its incentives. In a foreign-input intensive IJV $(\eta>1 / 2)$, the local firm is the minority partner. In this case, it is optimal to allocate a larger ownership share to the local partner to provide it with more powerful incentives.

Next, we analyze the effect of contract enforceability on the efficiency of an IJV. By inserting the optimal contract $\left(s^{*}, t^{*}\right)$ into (18) and combining it with (12) and (13), we obtain:

$$
\pi_{m}^{*}=\lambda \Omega(1-2 \gamma)^{\frac{1}{1-\alpha}}=\hat{\pi}_{m}(1-2 \gamma)^{\frac{1}{1-\alpha}} .
$$

Equation (20) suggests that a multinational firm receives share $(1-2 \gamma)^{\frac{1}{1-\alpha}}$ of its profits under perfect contract enforcement. This share decreases in $\gamma$ and is not affected by foreign input intensity $\eta$. From our discussion, an increase in $\gamma$ reduces the efficiency of an IJV through two channels. First, it reduces parties' incentives to produce inputs, thus reducing joint revenue. Second, it increases the share of revenue that both parties waste on their ex post actions.

Interestingly, foreign input specificity $\eta$ does not affect the efficiency loss that an IJV faces. This observation together with Proposition 2 suggests that an IJV in an industry with a low or high foreign input intensity $\eta$ can be equally efficient as an IJV with an intermediate value of $\eta$ as long as the ownership structure is sufficiently adjusted to provide the minority partner with higher-powered incentives.

\footnotetext{
${ }^{12}$ Since $\Psi \leq \frac{1}{2}$ and $\frac{1}{2} \geq \gamma \geq \frac{1}{R}, \hat{s}>s^{*} \geq 0$ in local-input intensive industries $(\eta<1 / 2)$ and $1 \geq s^{*}>\hat{s}$ in foreign-input intensive industries $(\eta>1 / 2)$.
} 


\subsection{Cronyism}

Finally, we consider the case of cronyism. Let $\delta>0$ so that the cost of ex post adjustment is higher for the multinational firm than for its local partner $\left(\gamma_{d}>\gamma_{m}\right)$. In period 3 , both parties choose optimal $r_{i}$ for a given $(s, t, m, d)$. Solving (14) and (15) yields:

$$
\begin{aligned}
& r_{m}^{\circledast}=(\gamma-\delta) \ln ((\gamma-\delta) R) \\
& r_{d}^{\circledast}=(\gamma+\delta) \ln ((\gamma+\delta) R)
\end{aligned}
$$

where subscript $\circledast$ reflects optimum in an environment with cronyism. Combining (21) and (22) with (4) gives

$$
v^{\circledast}=s-\Delta
$$

where

$$
\Delta=r_{d}^{\circledast}-r_{m}^{\circledast} \geq 0 \text { and } \Delta=\Delta(R) .
$$

We infer from (23) and (24) that cronyism allows the local partner to ex post grab revenue share $\Delta$ from the multinational firm. It is straightforward to derive that $\Delta$ increases with $R$. As we demonstrate below, this implies that cronyism affects parties' incentives to contribute inputs.

In period 2, parties choose the inputs $m$ and $d$ for a given $(s, t)$. We use equations (21)-(24) to rewrite parties' maximization problems as:

$$
\begin{gathered}
\max _{m} \pi_{m}=(s-\Delta(R(m, d))-\gamma+\delta) R(m, d)-\rho m+t \\
\max _{d} \pi_{d}=(1-s+\Delta(R(m, d))-\gamma-\delta) R(m, d)-\omega d-t .
\end{gathered}
$$

From (23) - (26), cronyism affects parties' incentives to produce inputs, albeit differently. It reduces the multinational firm's incentives to produce inputs since the multinational firm considers that, ceteris paribus, producing more $m$ increases $R$ and thus increases the share $\Delta$ that the local partner grabs. Inversely, cronyism increases the local firm's incentives since producing more inputs $d$ increases $R$ and thus raises the share $\Delta$ that it grabs from the multinational firm.

In period 1, the multinational firm offers a take-it-or-leave-it contract $(s, t)$ to its local partner. In the appendix, we derive that it is optimal for a

multinational firm to choose ownership share $s^{\circledast}$ that allows it to obtain ex post revenue share $v^{\circledast}$ :

$$
v^{\circledast}=\hat{s}-\gamma \frac{1-2 \psi}{2 \eta-1}+\delta .
$$


We also demonstrate that there is a unique $s^{\circledast}$ that corresponds to $v^{\circledast}$.

If we compare (19) with $(27), v^{\circledast}$ consists of three terms. The first term is the multinational firm's optimal ownership share under perfect contract enforcement $\hat{s}$; the second term reflects the effect of imperfect contract enforceability; and the third term reflects the effect of cronyism. As is clear from (27) and as is depicted with a dashed and pointed line in Figure 1, a multinational firm thus should respond to an environment with cronyism $(\delta>0)$ by ensuring that its ex post revenue share increases with $\delta$. As we have explained above, this is because cronyism reduces the multinational's incentives to produce inputs, while it increases the local firm's incentives to produce inputs. Ensuring that the multinational firm's ex post revenue share increases with $\delta$ thus allows the IJV to increase the relative power of the multinational firm's incentives.

To obtain $v^{\circledast}$, a multinational firm needs to choose ownership share $s^{\circledast}$. By combining (23) with $(24)$ and $(27)$, it is straightforward to show that, ceteris paribus, the multinational firm's ownership share is larger in an environment with cronyism than in an environment without cronyism:

$$
s^{\circledast} \geq s^{*}=\hat{s}-\gamma \frac{1-2 \psi}{2 \eta-1} .
$$

We state this in the following Proposition:

Proposition 3 Ceteris paribus, a multinational firm's ownership share in an IJV is higher in an environment with cronyism $(\delta>0)$ than in an environment without cronyism $(\delta=0)$.

Note that the multinational firm cannot always obtain $v^{\circledast}$ through its choice of $s^{\circledast}$. Specifically, if $v^{\circledast}+\Delta>1$, it is required to choose $s^{\circledast}>1$, which is not possible. In this case, it is profit-maximizing to choose $s^{\circledast}=1$. But this exclusive ownership goes against the notion of a joint venture. We infer that cronyism negatively affects the feasibility of forming an IJV. Two types of IJVs are particularly prone to become unfeasible in an environment with cronyism. First, an IJV with a higher foreign-input intensity $\eta$ is more likely to become unfeasible since this type of joint venture requires a higher $v^{\circledast}$, thus increasing the likelihood that $s^{\circledast}=1$. Second, an IJV with higher productivity $\theta$ is more likely to become unfeasible since this type of joint venture has a higher $R$ and therefore a higher $\Delta$. This also increases the likelihood that $s^{\circledast}=1$. We state this in the following Proposition:

Proposition 4 Ceteris paribus, cronyism reduces the feasibility of an IJV. Feasibility is especially reduced when $\eta$ and $\theta$ are high. 
Finally, we in the appendix derive the multinational firm's profits under cronyism:

$$
\pi_{m}^{\circledast}=\pi_{m}^{*}=\hat{\pi}_{m}(1-2 \gamma)^{\frac{1}{1-\alpha}} .
$$

Interestingly, equation (29) suggests that cronyism does not entail an extra efficiency loss. That is, for $s^{\circledast}<1$, the multinational firm's profits are identical to its profits with $\delta=0$ (equation (20)). Still, from Proposition 4, we expect fewer IJVs to be formed when cronyism is present since it reduces the feasibility of an IJV.

\section{$3 \quad$ Entry mode}

In this Section, we introduce the IJV model into an industry equilibrium framework similar to Antràs and Helpman (2004) to analyze the impact of the institutional features on a multinational firm's optimal entry mode. Consider an industry-equilibrium model where a continuum of multinational firms decide on their entry mode into a foreign market. We assume that the multinational firms need to be physically located in the host country to sell their products. ${ }^{13}$ Local consumers are assumed to spend a constant share of their income on the multinational firm's products. They have DixitStiglitz preferences that gives rise to the inverse demand function (1), where $\lambda$ depicts the aggregate consumption index. Since there is a continuum of firms, each multinational firm takes $\lambda$ as given.

For the production of a final good variety, two parties are required: a multinational firm that produces inputs $m$ and a local entity that produces inputs $d$. Parties face a perfectly elastic supply of the unique factor of production, labor. Wages are fixed so that the cost of producing a foreign input is parameter $\rho$ and the cost of producing a local input is parameter $\omega$. Final goods are produced using the Cobb-Douglas production function (2).

Similar to Melitz (2003), multinational firms differ in their productivity. To learn its productivity, a multinational firm incurs an irreversible fixed cost of entry equal to $F_{e}$. Upon paying this fixed cost, it learns its productivity level $\theta$, which is randomly drawn from a known cumulative distribution function $G(\theta)$. After observing its productivity level, it then decides whether to enter the host country market. Multinational firms have two entry mode options. First, to form an IJV with a local firm (denoted by superscript $J$ ). Second, to set up a wholly-owned subsidiary (denoted by superscript $V$ ).

\footnotetext{
${ }^{13}$ This assumption rules out market entry through exports from a multinational firm's home country.
} 
We assume that under both entry modes, a multinational firm signs a linear revenue-sharing contract $(s, t)$ with a local entity.

There is a key trade-off between both entry modes. On one hand, forming an IJV entails a lower fixed cost than setting up a subsidiary since it provides the multinational firm with access to local firms' market specific knowledge and contacts: $\kappa^{V}>\kappa^{J}$. On the other hand, setting up a subsidiary implies lower transaction costs since, unlike for an IJV, contracts are considered perfectly enforceable under this entry mode.

The industry-equilibrium model can be summarized by the following sequences of moves: in period 0 , each multinational firm decides whether it enters the host country. If it enters, it incurs a fixed cost $F_{e}$ to have its productivity level $\theta$ realized. In period 1 , the multinational firm decides if it wants to produce output or remain idle. If it decides to produce output, it chooses to enter the market by forming an IJV with a local partner or by setting up its own subsidiary. In period 2, the multinational firm signs a revenue-sharing contract $(s, t)$ with its local partner or subsidiary. In period 3 , both parties produce their inputs. In period 4 , IJV partners can take costly ex post actions to improve their revenue share. The final goods are then produced and sold.

We can solve the model through backward induction. For periods 2-4, we can rely on our derivations in Section 2. Specifically, we can use (20) to infer that if a multinational firm signs an imperfectly enforceable IJV contract with a local firm, it earns the following profits:

$$
\pi_{m}^{J}=\lambda \Omega(1-2 \gamma)^{\frac{1}{1-\alpha}}-\kappa^{J} .
$$

Similarly, we can use (12) to infer that if a multinational firm signs a perfectly enforceable contract with its subsidiary, it earns profits:

$$
\pi_{m}^{V}=\lambda \Omega-\kappa^{V} .
$$

In period 1, each multinational firm considers profits functions (30) and (31) to decide its optimal entry mode. In Figure 2, we plot both profit functions to graphically analyze the role of productivity on a multinational firm's optimal entry mode. We depict $\theta^{\frac{\alpha}{1-\alpha}}$ on the horizontal axis and the multinational firm's profit on the vertical axis. In addition, we define $\theta_{1}$ as the productivity level where $\pi_{m}^{J}=\pi_{m}^{V}$.

[Figure 2 about here] 
Figure 2 demonstrates that less productive firms with $\theta \leq \theta_{1}$ choose to form an IJV with a local partner, while more productive firms with $\theta>\theta_{1}$ choose to set up a wholly-owned subsidiary. This suggests that less productive multinational firms choose to focus on the mitigation of ex ante LOF by forming an IJV, while more productive multinational firms focus on the mitigation of transaction costs by setting up a wholly-owned subsidiary. We state this in the following Proposition:

Proposition 5 Ceteris paribus, forming an IJV is optimal for low productivity firms with $\theta \leq \theta_{1}$; setting up a wholly-owned subsidiary is optimal for high productivity firms with $\theta>\theta_{1}$.

\section{Conclusion}

The question at the heart of this paper is how multinational firms should adapt their ownership strategy when facing the institutional features of contract enforceability and cronyism. To address this, we have set up an IJV model where both the multinational firm and its local partner can ex post take costly actions to increase their revenue share. We have shown that the IJV's optimal ownership structure in such a model is determined by both institutional features. Specifically, lower contract enforceability (higher $\gamma$ ) disproportionately weakens the incentives of the minority partner in an IJV. As a result, it is optimal for a multinational firm to allocate a larger ownership share to the minority partner in the IJV. Cronyism (higher $\delta$ ) weakens the incentives of the multinational firm to contribute inputs to the IJV while strengthening the incentives of the local firm. The multinational firm thus should receive a larger ownership share in the IJV.

Next, we have introduced the IJV model into an industry-equilibrium setup to study the effect of the institutional features on a multinational firm's entry mode. We have demonstrated that, in an environment with low contract enforceability and cronyism, more productive multinational firms will set up their own subsidiary, but that less productive multinationals will form an IJV. We have also shown that lower contract enforceability and higher cronyism both increase the prevalence of wholly-owned subsidiaries in an industry. Our analysis identifies testable hypotheses relating institutional features with a multinational firm's optimal ownership strategy. This opens the door for empirical studies. 


\section{Appendix}

In this appendix, we solve the IJV model with cronyism (section 2.3) through backward induction.

Period 3. For a given $(s, t, m, d)$, parties solve

$$
\begin{gathered}
\max _{r_{m}} \pi_{m}=\left(s-r_{d}+r_{m}\right) R-e^{\frac{r_{m}}{\gamma-\delta}}-\rho m+t \\
\max _{r_{d}} \pi_{d}=\left(1-s+r_{d}-r_{m}\right) R-e^{\frac{r_{d}}{\gamma+\delta}}-\omega \cdot d-t
\end{gathered}
$$

The solution of these problems gives:

$$
\begin{aligned}
& r_{m}^{\circledast}=(\gamma-\delta)(\ln R+\ln (\gamma-\delta)) \\
& r_{d}^{\circledast}=(\gamma+\delta)(\ln R+\ln (\gamma+\delta)) .
\end{aligned}
$$

To simplify notation below, let

$$
\Delta(R)=r_{d}^{\circledast}-r_{m}^{\circledast}=2 \delta \ln R+(\gamma+\delta) \ln (\gamma+\delta)-(\gamma-\delta) \ln (\gamma-\delta) .
$$

Then, the multinational firm's ex post revenue share is

$$
v=s-\Delta(R) .
$$

Period 2. For a given $(s, t)$, parties choose inputs $m$ and $d$. By inserting (A-3) and (A-4) into (A-1) and (A-2), their maximization problems can be reduced to:

$$
\begin{gathered}
\max _{m} \pi_{m}=(s-\Delta(R)-\gamma+\delta) R-\rho m+t \\
\max _{d} \pi_{d}=(1-s+\Delta(R)-\gamma-\delta) R-\omega d-t,
\end{gathered}
$$

where $R$ is a shortcut for $R(m, d)$, which is given by (3).

Next, we will demonstrate that when $\alpha \in(0,1 / 2)$ for any fixed $s$, there exists a unique optimal $m^{\circledast}$ and $d^{\circledast}$, and, therefore a unique $v(s)$. This permits us to use $v$ as the choice variable in period 1 , which will make our calculations easier. Due to parties' optimization,

$$
\frac{\partial \pi_{m}}{\partial m}=0 \text { and } \frac{\partial \pi_{d}}{\partial d}=0 .
$$

The uniqueness of $m^{\circledast}$ and $d^{\circledast}$ is then assured if:

$$
\frac{\partial^{2} \pi_{m}}{[\partial m]^{2}} \leq 0 \text { and } \frac{\partial^{2} \pi_{d}}{[\partial d]^{2}} \leq 0 .
$$


If we solve problems (A-7) and (A-8),

$$
\begin{gathered}
\frac{\partial \pi_{m}}{\partial m}=(s-\Delta(R)-\gamma-\delta) \frac{\alpha \eta R}{m}-\rho=0 \\
\frac{\partial \pi_{d}}{\partial d}=(1-s+\Delta(R)-\gamma+\delta) \frac{\alpha(1-\eta) R}{d}-\omega=0 .
\end{gathered}
$$

where we use (3) and (A-5) to derive that

$$
\frac{\partial R}{\partial m}=\frac{\alpha \eta R}{m} \text { and } \frac{\partial R}{\partial d}=\frac{\alpha(1-\eta) R}{d} \text { and } \frac{d \Delta(R)}{d R}=\frac{2 \delta}{R} .
$$

We can then use (A-9) and(A-10) to determine that $m^{\circledast}$ and $d^{\circledast}$ are unique as long as $\alpha \leq 1 / 2$. Specifically, if $\alpha \leq 1 / 2$,

$$
\frac{\partial^{2} \pi_{m}}{[\partial m]^{2}}=\frac{\alpha \eta R}{m^{2}}((s-\Delta(R)-\gamma-\delta)(\alpha \eta-1)-2 \delta \alpha \eta) \leq 0
$$

and

$$
\frac{\partial^{2} \pi_{d}}{[\partial d]^{2}}=\frac{\alpha(1-\eta) R}{d^{2}}((1-s+\Delta(R)-\gamma-\delta)(\alpha(1-\eta)-1)+2 \delta(2 \alpha(1-\eta)-1)) \leq 0,
$$

where we infer from (A-9) that $s-\Delta(R)-\gamma-\delta \geq 0$ and from (A-8) that $1-s+\Delta(R)-\gamma-\delta \geq 0$.

Uniqueness of $m^{\circledast}$ and $d^{\circledast}$ then permits us to use $v$ as an independent variable, and find $s=s(v), m(v), d(v)$ and $R(v)$. If we combine (A-6), (A-9) and (A-10),

$$
\frac{m}{\eta}=\frac{(v-\gamma-\delta) R \alpha}{\rho}
$$

and

$$
\frac{d}{1-\eta}=\frac{(1-v-\gamma+\delta) R \alpha}{\omega} .
$$

We can then insert (A-11) and ((A-12)) into (3) to express $R$ as a function of $v$ :

$$
R(v)=\lambda\left[\alpha \theta\left(\frac{v-\gamma-\delta}{\rho}\right)^{\eta}\left(\frac{1-v-\gamma+\delta}{\omega}\right)^{1-\eta}\right]^{\frac{\alpha}{1-\alpha}}
$$

Combining (A-11), (A-12) and (A-13) then yields:

$$
m(v)=\frac{(v-\gamma-\delta) \alpha \eta}{\rho} R(v)
$$


and

$$
d(v)=\frac{(1-v-\gamma+\delta) \alpha(1-\eta)}{\omega} R(v)
$$

Period 1. In period 1, the multinational firm solves for the optimal contract $(s, t)$. Since there is a unique $v^{\circledast}$ corresponding to $s^{\circledast}$, we can use $v$ as the choice variable. We can express the multinational firm's maximization problem as:

$$
\max _{v, t} \pi_{m}=(v-\gamma+\delta) R(v)-\rho m(v)+t
$$

subject to

$$
\pi_{d}=(1-v-\gamma-\delta) R(v)-\omega d(v)-t \geq 0,
$$

which simplifies to:

$$
\max _{v} \pi_{m}=((1-\alpha \eta)(1-2 \gamma)-\alpha(1-v-\gamma+\delta)) R(v)
$$

We can then solve (A-16) to obtain $v^{\circledast}$ :

$$
v^{\circledast}=\hat{s}-\gamma \frac{1-2 \psi}{2 \eta-1}+\delta
$$

where $\hat{s}$ is given by (10). From (A-6), we can obtain the corresponding $s^{\circledast}$ as

$$
s^{\circledast}=v^{\circledast}+\Delta\left(R^{\circledast}\right)
$$

Finally, we can insert (A-17) into (A-16) and combine with (20) to derive the multinational firm's profits:

$$
\pi_{m}^{\circledast}=\pi_{m}^{*}=\hat{\pi}_{m}(1-2 \gamma)^{\frac{1}{1-\alpha}} .
$$




\section{References}

[1] Antràs, P., 2003. Firms, contracts and trade structure. Quarterly Journal of Economics 68, 1375-1418.

[2] Antràs, P., 2005. Incomplete contracts and the product cycle. American Economic Review 45, 1054-1073.

[3] Antràs, P., Helpman, E., 2004. Global sourcing. Journal of Political Economy 112, 552-580.

[4] Antràs, P., Helpman, E., 2008. Contractual frictions and global sourcing, in: Helpman, E., Marin, D.,Verdier, T. (Eds.), The Organization of Firms in a Global Economy, Harvard University Press, Cambridge.

[5] Bai, C., Tao, Z., Wu, C., 2004. Revenue sharing and control rights in team production: theories and evidence from joint ventures. Rand Journal of Economics 35, 277-305.

[6] Buckley, P., Casson, M., 1976. The Future of the Multinational Enterprise. MacMillan, London.

[7] Caves, R., 1982. Multinational Enterprise and Economic Analysis. Cambridge University Press, New York.

[8] Desai, M., Moel, A., 2008. Czech mate: expropriation and investor protection in a converging world. Review of Finance 12, 221-251.

[9] Dunning, J., 1977. Trade, location of economic activity and the MNE: a search for an eclectic approach, in: Ohlin, B., Hesselborn, P., Wijkman, P. (Eds.), The International Allocation of Economic Activity, Holmes \& Meyer, New York, pp. 395-418.

[10] Eden, L., Miller, S., 2004. Distance matters: liability of foreignness, institutional distance and ownership strategy, in: Hitt, M., Cheng J. (Eds.), The Evolving Theory of the Multinational Firm, Advances in International Management, Volume 16, Elsevier, Amsterdam, pp. 187221.

[11] Grossman, G., Helpman, E., 2002. Integration versus outsourcing in industry equilibrium. Quarterly Journal of Economics 117, 85-120.

[12] Grossman, G., Helpman, E., 2003. Outsourcing versus FDI in industry equilibrium. Journal of the European Economic Association 1, 317-327. 
[13] Grossman, G., Helpman, E., 2005. Outsourcing in a global economy. Review of Economic Studies 72, 135-159.

[14] Helpman, E., 2006. Trade, FDI, and the organization of firms. Journal of Economic Literature 44, 589-630.

[15] Henisz, W., 2000. The institiutional environment for multinational investment. The Journal of Law, Economics and Organization 16, 334364 .

[16] Hennart, J., 1982. A Theory of Multinational Enterprise. University of Michigan Press, Ann Arbor.

[17] Hennart, J. 1988. A transaction cost theory of equity joint ventures. Strategic Management Journal 9, 361-374.

[18] Hennart, J., 1991. The transaction costs theory of joint ventures: an empirical study of japanese subsidiaries in the United States. Management Science 17, 483-497.

[19] Huang, Y., 2005. Are foreign firms privileged by their host governments? Evidence from the 2000 world business environment survey. MIT Sloan Working Paper No. 4538-05.

[20] Hymer, S., 1976. The International Operations of National Firms: A Study of Direct Investment. MIT Press, Cambridge.

[21] Inkpen, A., Beamish, P., 1997. Knowledge, bargaining power, and the instability of international joint ventures. Academy of Management Review 22, 177-203.

[22] Luo, Y., 2002. Capability exploitation and building in a foreign market: implications for multinational enterprises. Organizational Studies 13, 48-63.

[23] Melitz, M., 2003. The impact of trade on intra-industry reallocations and aggregate industry productivity. Econometrica 71, 1695-1725.

[24] Perkins, S., Morck, R., Yeung, B., 2007. Innocents abroad: failure rates of international joint ventures with pyramidal groups. Mimeo.

[25] Spencer, B., 2005. International outsourcing and incomplete contracts. Canadian Journal of Economics 38, 1107-1135. 
[26] Wang, S.; Zhu, T., 2005. Control allocation, revenue sharing, and joint ownership. International Economic Review 46, 895-915.

[27] Zaheer, S., 1995. Overcoming the liability of foreignness. The Academic of Management Journal 38, 341-363.

[28] Zaheer, S., 2002. The liability of foreignness, redux: a commentary. Journal of International Management 8, 351-358. 


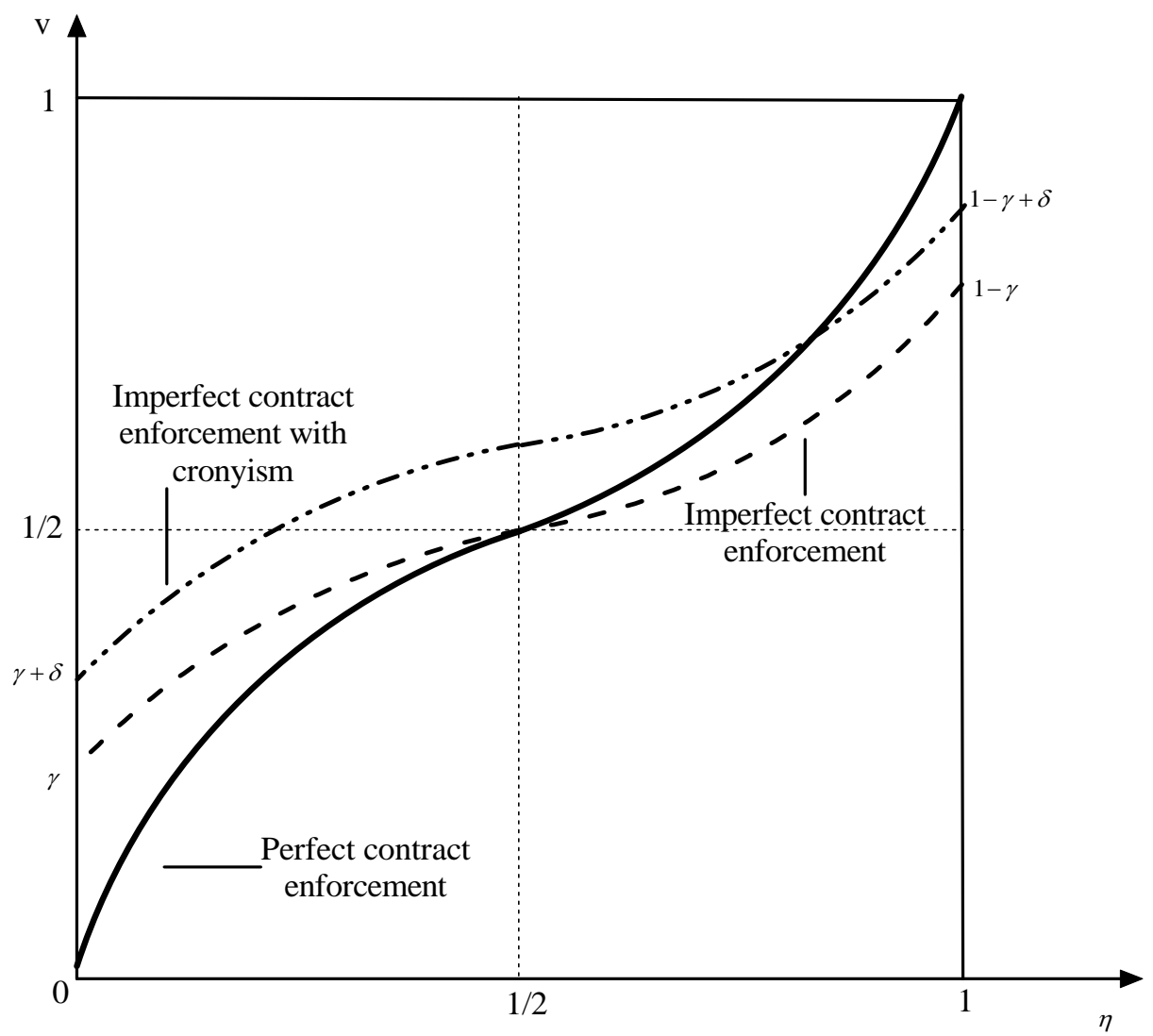

Figure 1: Optimal ex post revenue distribution in an IJV 


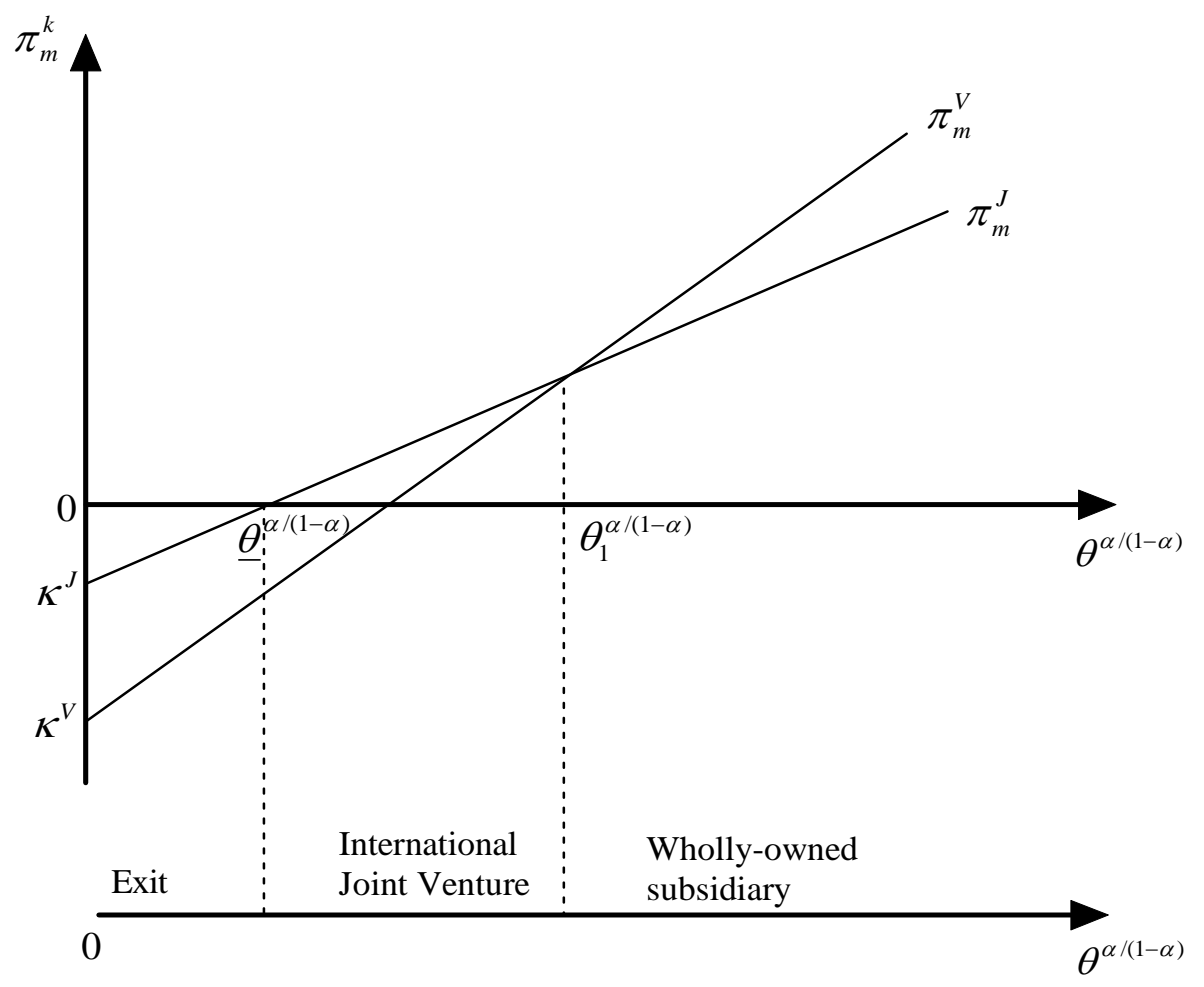

Figure 2: Productivity and Entry Mode 